\title{
Serial estimation of serum albumin and its role in traumatic brain injury patients
}

\author{
Mithilesh Kumar Pandey', Sunil Kumar Baranwal'2, Deepak Singh Panwar ${ }^{3}$, Suniti Kumar \\ Saha ${ }^{4}$, Kaushik Roy ${ }^{5}$, Subhasis Ghosh ${ }^{6}$, Parimal Tripathy ${ }^{7}$ \\ ${ }^{1}$ Assistant Professor, Department of Neurosurgery, Government Medical College Haldwani, Nainital, Uttarakhand, \\ India, ${ }^{2}$ Post Doctoral Trainee Student, Department of Neurosurgery, Nil Ratan Sircar Medical College and Hospital, \\ Kolkata, ${ }^{3}$ Consultant Neurosurgeon, Department of Neurosurgery, Government Medical College Haldwani, Nainital, \\ Uttarakhand, India, ${ }^{4}$ Professor \& HOD, Department of Neurosurgery, Nil Ratan Sircar Medical College and Hospital, \\ Kolkata, ${ }^{5}$ Associate Professor, Department of Neurosurgery, Nil Ratan Sircar Medical College and Hospital, Kolkata, \\ ${ }^{6}$ Professor, Department of Neurosurgery, Nil Ratan Sircar Medical College and Hospital, Kolkata, ${ }^{7}$ Former, HOD \& \\ Professor, Department of Neurosurgery, Nil Ratan Sircar Medical College and Hospital, Kolkata
}

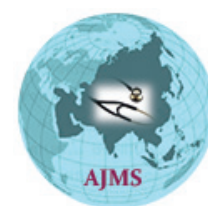

A B S T R A C T

Background: Serum albumin is routinely measured; cheap and easily available test even in remote areas laboratories. Albumin is the major protein of human plasma and one of the negative acute phase reactants reported to fall as a component of metabolic response to injury or infection, independent of the nutritional status. Even though this has also been noted in patients with head injury and its overall significance with respect to neurological outcome following head injury are yet to be established. Aims and Objectives: To assess the role of serum albumin in outcome of head injury patient. Materials and Methods: This is a prospective case control study. Total 200 cases of traumatic brain injury [152 male and 48 female] were studied in NRS Medical College, Kolkata from September 2012 to October 2013. Serum albumin estimation, along with clinical and radiological data was collected. Serum albumin was compared between among various subgroups and outcome was assessed by Glasgow Coma Scale at 6 months. Results: In present study 86 (43\%) patients having hypoalbuminemia $(<3.5 \mathrm{gm} / \mathrm{dl}$ ) and falling trend in admission serum albumin levels from day 1 to $10^{\text {th }}$ day with decrement in GCS was statistically highly significant ( $<0.001$ ) as hypoalbuminemia was noted in $68 \%, 39.65$ and $33.43 \%$ patients with severe, moderate and mild head injury respectively. The present study was showed that female TBI patients having less no. of hypoalbuminemia compare to male as $77.7 \%, 45.4 \%, 31.4 \%$ male and $42.8 \%, 28.5 \%, 27.2 \%$ female having hypoalbuminemia $(<3.5 \mathrm{gm} / \mathrm{dl})$ in severe, moderate and mild head injury respectively and statistically significant difference in severe and moderate group. Conclusion: The serial estimation of serum albumin in traumatic brain injury patients provides the treating doctor an insight in the prognosis of the patient so that they can be managed aggressively.

Key words: Traumatic brain injury, Hypoalbuminemia, Glasgow Coma Scale, Glasgow Outcome Scale, Bromocresol green

\section{INTRODUCTION}

All neurological damage does not occur at the moment of impact but evolves over the ensuing hours and days, with the primary injury initiating a secondary injury cascade, leading to deleterious pathophysiological and biochemical reactions. ${ }^{1}$ Albumin is the major protein of human plasma and one of the negative acute phase reactants reported to fall as a component of metabolic response to injury independent of the nutritional status. ${ }^{2,3}$

Only a few biochemical markers have been identified to prognosticate the severity of trauma at the tissue level. ${ }^{4}$ To explore the efficacy of albumin as a neuroprotective agent 
for TBI in humans, a randomized controlled trial, Albumin for Intracerebral Hemorrhage Intervention (ACHIEVE), is underway. ${ }^{5}$ Although this issue is still controversial but in his serum albumin levels and its overall significance with respect to neurological outcome following head injury are yet to be established. ${ }^{2,6,7}$

Despite the volume of research in this area, only few prospective studies in literatures were found on traumatic brain injury in relation to serum albumin.

In view of the above facts, this prospective study intends to evaluate the changes in the serum albumin levels in traumatic brain injury patients and its role on neurological outcome as an independent prognostic indicator to identify who are likely to have a poor outcome.

\section{MATERIALS AND METHODS}

This is a prospective cohort study with control. Total 200 cases of traumatic brain injury along with 50 healthy controls were studied in department of Neurosurgery NRS Medical College, Kolkata from September 2012 to October 2013. Data regarding clinical and radiological status of patient were collected. Severity of traumatic brain injury was defined according to Glasgow Coma Scale (GCS) at admission (mild: 14-15, moderate: 9-13, and severe $<9$ ).

\section{Exclusion criteria}

1. Patients less than 12 years and more than 60years.

2. Alcoholics.

3. Poly trauma pt.

4. Hepatic diseases, chronic renal failure and patient with cardio-respiratory diseases.

Daily clinical assessment was done along with repeat CT scan brain when need. The routine blood investigation along with serum albumin estimation was done at the time of admission and on day 3, 5 and 10. The serum samples were analyzed for albumin levels by bromocresol green [BCG] dye binding method using an auto analyzer XL- 600.

Standard protocol for management of head injury was given to study patients. Decision regarding surgical decompression was taken according to clinical and the computed tomography scan findings. Neuro ICU care and mechanical ventilator support was given when need. Oral or nasogastric tube feeding was initiated as early as possible. Parenteral hyperalimentation or albumin supplements were not given.

We have assessed the outcome of our patients on the basis of Glasgow Outcome Scale (GOS) at 6 months. The GOS was dichotomized as unfavorable group (grades 1,2, and 3) or favorable group (grades 4 and 5). Further we have divided the patients in two category as Survivor (GOS grade $2,3,4,5)$ and Non survivor (GOS grade 1).

Serum albumin levels on admission and on different days were compared between control population and TBI patients. Comparisons were also done among various subgroups defined by age, sex, severity of TBI and others.

Data collected in the study is to be analyzed with SPSS software (version 11) for the statistical analyses. The mean, standard deviation, and Chi-square test was used to analyze the data and $P<0.05$ was considered as statistically significant. Univariate and multivariate analysis was conducted with logistic regression adjusting for age, severity of TBI (GCS), and hypoalbuminemia (serum albumin $\leq 3.5 \mathrm{~g} / \mathrm{dl})$.

\section{RESULTS}

In the present study $152(76 \%)$ male, $48(24 \%)$ female with traumatic brain injury and 50 ages \& sex matched healthy controls were studied. The incidence of head injury is more common in the $3^{\text {td }}$ and $4^{\text {th }}$ decade with male $\&$ female ratio of (3.1:1). 24\% patients of severe to moderate traumatic brain injury have contusion and 28\% cases of TBI having multiple intracranial injuries (Table 1a).

The mean age at admission is higher for unfavorable group (39.24 years) compare to favorable group ( $37.55 \mathrm{yrs}$ ) and on admission mean serum albumin levels in patients of

\begin{tabular}{lcc}
$\begin{array}{l}\text { Table 1a: Distribution of traumatic brain injury } \\
\text { patients according to site of injuries. }\end{array}$ \\
\hline TBI & Frequency & Percent \\
\hline Contusion & 56 & 28.0 \\
E.D.H & 25 & 12.5 \\
I.C.H & 10 & 5.0 \\
Multiple ICI & 56 & 28.0 \\
S.A.H & 28 & 14.0 \\
S.D.H & 25 & 12.5 \\
Total & 200 & 100.0 \\
\hline
\end{tabular}

EDH: Extradural hematoma, ICH: Intracerebral hemorrhage, ICI: Intracranial injury, SAH: Subarachnoid hemorrhage, SDH: Subdural hemorrhage

\begin{tabular}{|c|c|c|c|c|}
\hline \multirow[t]{2}{*}{ Variables } & \multicolumn{2}{|c|}{ Mean $\pm S D$} & \multirow[t]{2}{*}{ t-value } & \multirow[t]{2}{*}{$p$-value } \\
\hline & Study group & Control group & & \\
\hline Age & $38.84 \pm 11.122$ & $38.22 \pm 11.114$ & 0.355 & 0.723 \\
\hline $\begin{array}{l}\text { Serum albumin } \\
\text { day } 1\end{array}$ & $3.760 \pm 0.339$ & $4.214 \pm 0.186$ & -9.109 & $<0.001$ \\
\hline
\end{tabular}


head injury were $3.760 \pm 0.339 \mathrm{~g} / \mathrm{dl}$ as compared to control $4.214 \pm 0.186 \mathrm{~g} / \mathrm{dl}$ (Table1b).

In present study on day 1 the mean serum total protein was $6.15(\mathrm{SD} \pm 0.94) \mathrm{g} / \mathrm{dl}$ and on $10^{\text {th }}$ day $6.18(\mathrm{SD} \pm 0.92) \mathrm{g} / \mathrm{dl}$. Levels showed insignificant $(p=0.548)$ increase from day 1 to day 10 (Figure 1a).

In present study $86(43 \%)$ patients having hypoalbuminemia $(<3.5 \mathrm{gm} / \mathrm{dl})($ Table1c).

At 6 months unfavorable outcome in TBI patients was noticed more in the group who had admission hypoalbuminemia, as compared to those having normal levels and the difference was statistically highly significant $(\mathrm{p}<0.001)$ (Table1d).

Although statistically insignificant outcome difference was observed gender wise but less no. of female patient in unfavorable group $7(14.9 \%)$ than male $40(85.1 \%)$ (Table 1e).

Comparison of serum albumin among various subgroup in TBI patients on different days [day 1,3,5,10] illustrated here in different tables below from Table $2 \mathrm{a}$ to $2 \mathrm{~d}$.

Statistically significant mortality in TBI patients where the serum albumin $<3.5 \mathrm{gm} / \mathrm{dl}$ on comparing where $\geq 3.5 \mathrm{gm} / \mathrm{dl}(\mathrm{p}<0.001)$ (Table $2 \mathrm{~d})$.

$88.5 \%$ patients were discharged with improved neurological status and $(11.5 \%)$ were succumbed in present study with majority of them were in unfavorable group (22 among 23)
(Figure 1b). 20 male patients died in unfavorable group(40) and 2 patient in favorable group(112) and 1 female patient died in unfavorable group (7) statistically significant gender wise mortality differences observed $(\mathrm{p}<0.001)$.

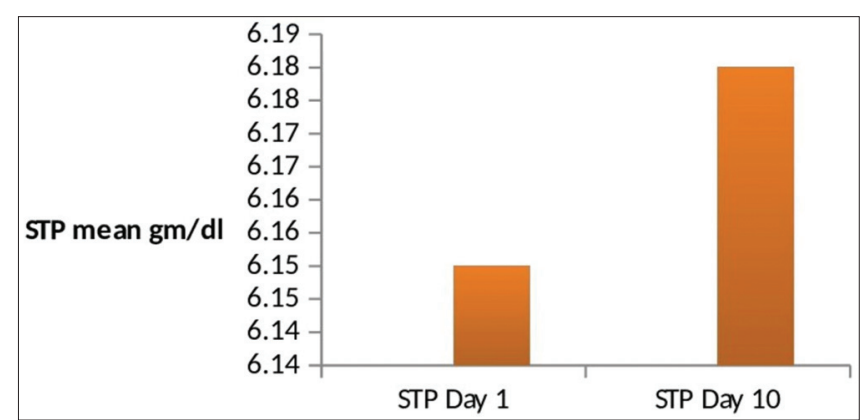

Figure 1a: Comparison of serum total protein level on two different days in study group

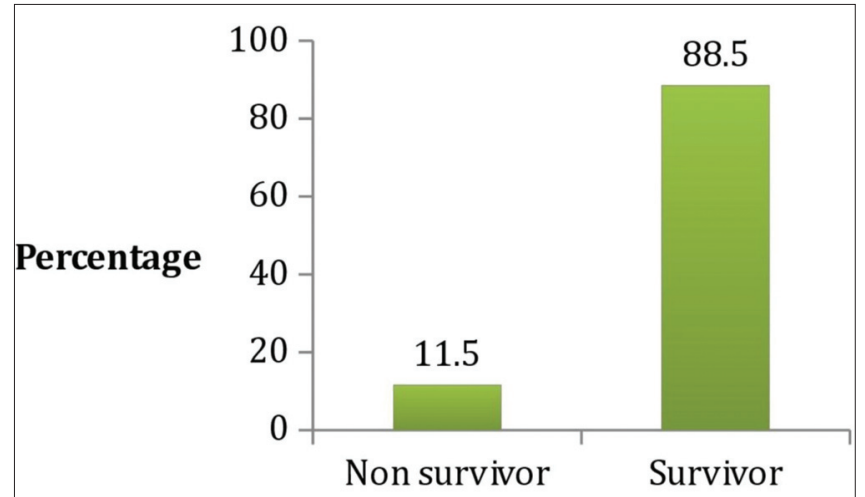

Figure 1b: Distribution of TBI patients in two groups' survivor [live] and non survivor [dead]

\begin{tabular}{|c|c|c|c|c|}
\hline \multirow{2}{*}{$\begin{array}{l}\text { Severity } \\
\text { of TBI }\end{array}$} & \multicolumn{2}{|c|}{ Male } & \multicolumn{2}{|c|}{ Female } \\
\hline & $\begin{array}{l}\text { Total no. } \\
\text { patients }\end{array}$ & $\begin{array}{l}\text { Hypoalbuminemia } \\
(<3.5 \mathrm{gm} / \mathrm{dl}) \%\end{array}$ & $\begin{array}{l}\text { Total no. } \\
\text { patients }\end{array}$ & $\begin{array}{c}\text { Hypoalbuminemia } \\
(<3.5 \mathrm{gm} / \mathrm{dl}) \%\end{array}$ \\
\hline Mild & 72 & 30.50 & 20 & 27.20 \\
\hline Moderate & 44 & 43 & 14 & 28.50 \\
\hline Severe & 36 & 77.60 & 14 & 42.80 \\
\hline
\end{tabular}

\begin{tabular}{|c|c|c|c|c|}
\hline \multirow{3}{*}{$\begin{array}{l}\text { Serum albumin } \\
\text { in } \mathrm{gm} / \mathrm{dl}\end{array}$} & \multicolumn{4}{|c|}{ GOS } \\
\hline & \multicolumn{2}{|c|}{ Favorable group } & \multicolumn{2}{|c|}{ Unfavorable group } \\
\hline & No. & $\%$ & No. & $\%$ \\
\hline$<3.5$ & 50 & 32.7 & 36 & 76.6 \\
\hline$\geq 3.5$ & 103 & 67.3 & 11 & 23.4 \\
\hline Total & 153 & 100 & 47 & 100 \\
\hline
\end{tabular}


Table 2a: Comparison of serum albumin among TBI patients divided according to severity on different days.

\begin{tabular}{|c|c|c|c|c|c|}
\hline \multirow{2}{*}{$\begin{array}{l}\text { Days of serum } \\
\text { albumin estimation }\end{array}$} & \multicolumn{3}{|c|}{ S alb gm/dl (mean $\pm S D)$} & \multirow[t]{2}{*}{ f-value } & \multirow[t]{2}{*}{ p-value } \\
\hline & Mild head injury & Moderate head injury & Severe head injury & & \\
\hline Day 1 & $3.859 \pm 0.313$ & $3.727 \pm 0.296$ & $3.614 \pm 0.375$ & 9.629 & $<0.001$ \\
\hline Day 3 & $3.673 \pm 0.360$ & $3.481 \pm 0.310$ & $3.272 \pm 0.354$ & 22.401 & $<0.001$ \\
\hline Day 5 & $3.595 \pm 0.340$ & $3.405 \pm 0.374$ & $3.080 \pm 0.454$ & 29.567 & $<0.001$ \\
\hline Day 10 & $3.569 \pm 0.365$ & $3.344 \pm 0.404$ & $2.968 \pm 0.476$ & 35.477 & $<0.001$ \\
\hline
\end{tabular}

\begin{tabular}{|c|c|c|c|c|}
\hline \multirow{2}{*}{$\begin{array}{l}\text { Days of serum } \\
\text { albumin } \\
\text { estimation }\end{array}$} & \multicolumn{2}{|c|}{ S alb gm/dl (mean $\pm S D)$} & \multirow[t]{2}{*}{ t-value } & \multirow[t]{2}{*}{$p$-value } \\
\hline & Survivor & Non survivor & & \\
\hline Day 1 & $3.81 \pm 0.30$ & $3.35 \pm 0.6$ & 10.346 & 0.001 \\
\hline Day 3 & $3.58 \pm 0.51$ & $3.01 \pm 0.22$ & 13.590 & 0.001 \\
\hline Day 5 & $3.49 \pm 0.50$ & $2.74 \pm 0.32$ & 15.443 & 0.001 \\
\hline Day 10 & $3.44 \pm 0.51$ & $2.63 \pm 0.37$ & 22.328 & 0.001 \\
\hline
\end{tabular}

Table 2c: Comparison of serum albumin among gender on different days

\begin{tabular}{|c|c|c|c|c|}
\hline \multirow{2}{*}{$\begin{array}{l}\text { Days of } \\
\text { serum } \\
\text { albumin } \\
\text { estimation }\end{array}$} & \multicolumn{2}{|c|}{$\mathrm{S}$ alb in gm/dl (mean $\pm S D)$} & \multirow[t]{2}{*}{ t-value } & \multirow[t]{2}{*}{ p-value } \\
\hline & Male & Female & & \\
\hline Day 1 & $3.751 \pm 0.332$ & $3.787 \pm 0.364$ & -0.643 & 0.521 \\
\hline Day 3 & $3.503 \pm 0.382$ & $3.560 \pm 0.374$ & -0.896 & 0.372 \\
\hline Day 5 & $3.381 \pm 0.450$ & $3.506 \pm 0.360$ & -1.748 & 0.082 \\
\hline Day 10 & $3.316 \pm 0.491$ & $3.472 \pm 0.383$ & -2.018 & 0.045 \\
\hline
\end{tabular}

\begin{tabular}{|c|c|c|c|c|}
\hline \multirow{2}{*}{$\begin{array}{l}\text { Days of serum } \\
\text { albumin } \\
\text { estimation }\end{array}$} & \multicolumn{2}{|c|}{ S alb gm/dl (mean $\pm S D)$} & \multirow[t]{2}{*}{ t-value } & \multirow[t]{2}{*}{ p-value } \\
\hline & Survivor & Non survivor & & \\
\hline Day 1 & $3.81 \pm 0.30$ & $3.35 \pm 0.6$ & 10.346 & 0.001 \\
\hline Day 3 & $3.58 \pm 0.51$ & $3.01 \pm 0.22$ & 13.590 & 0.001 \\
\hline Day 5 & $3.49 \pm 0.50$ & $2.74 \pm 0.32$ & 15.443 & 0.001 \\
\hline Day 10 & $3.44 \pm 0.51$ & $2.63 \pm 0.37$ & 22.328 & 0.001 \\
\hline
\end{tabular}

$87 \%$ patients were managed conservatively and rests were managed surgically. Out of 26 patient who were managed surgically $22(14.4 \%)$ patient in favorable group and 4 patients in unfavorable group. The difference was statistically insignificant ( $p=0.295)$ (Figure 1c).

In present study the mean duration of neuro ICU stay was $8.08( \pm 3.008)$ days and $3.84( \pm 2.433)$ days in group of albumin less than $3.5 \mathrm{gm} / \mathrm{dl}$ and more than $3.5 \mathrm{gm} / \mathrm{dl}$ respectively and difference was statistically significant $(p<0.001)$ (Figure $1 d)$. In our study statistically significant $(p=0.011)$ difference in the mean duration of mechanical ventilation was observed between group of hypoalbuminemia and normoalbuminemia $5.92( \pm 3.008)$ days and $3.50( \pm 2.433)$ respectively (Figure $1 \mathrm{~d})$.

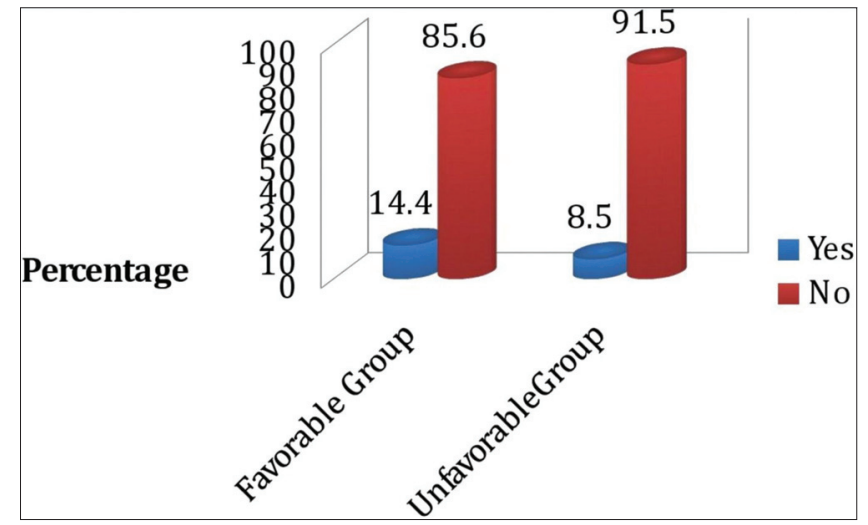

Figure 1c: Distribution of surgical managed patient in outcome groups

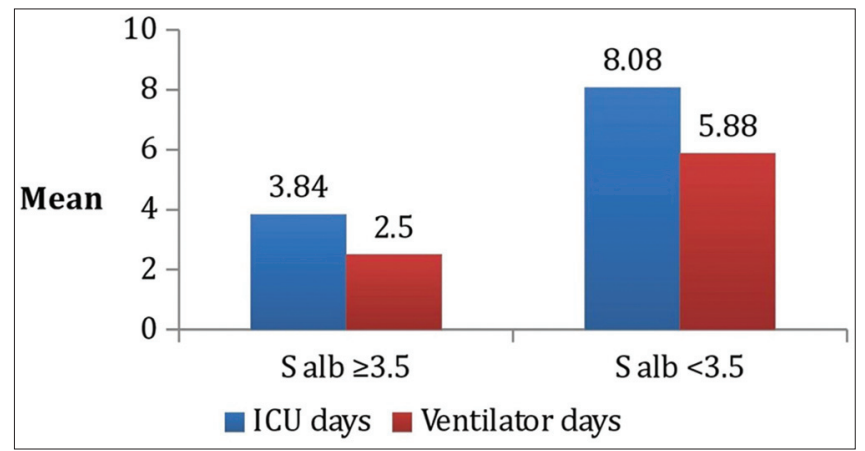

Figure 1d: Comparison of serum albumin and Neuro ICU stay \& (MV) mechanical ventilator days

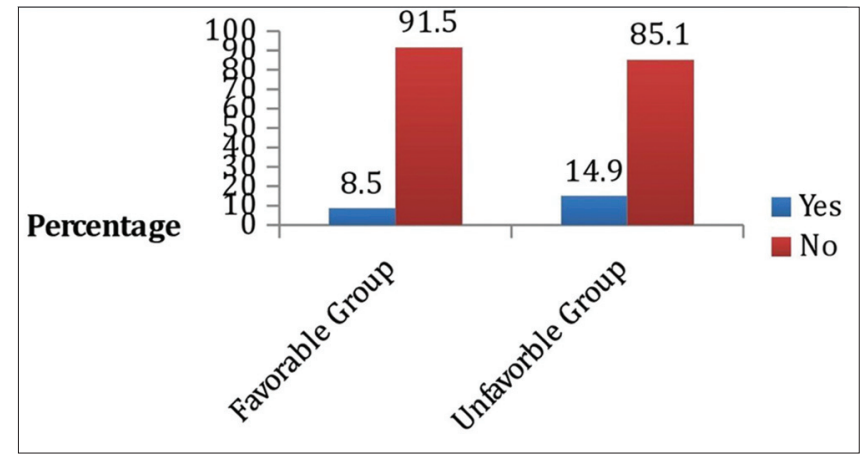

Figure 1e: Comparison of complications among favorable and unfavorable groups

This study showed that the complications like infection, delayed wound healing was higher for unfavorable group $(14.9 \%)$ than in favorable group (8.5\%), although the difference was statically insignificant $(p=0.201)$ (Figure 1e). 


\section{DISCUSSION}

In the present study (Table 1c) 25\% severe and 75\% mild to moderate head injury patients were included and the sample size was comparable with study of Du Chen, et al. ${ }^{8}$

Dhandapani SS et $\mathrm{al}^{9}$ and Bernard F, et $\mathrm{al}^{6}$ were recorded serum albumin levels until day 21 after head injury. Young et al. ${ }^{10}$ noted hypoalbuminemia to last for at least 3 weeks following traumatic brain injury. Keeping in view the above mentioned facts in the present study we have measured the serum albumin level in a traumatic brain injury patient in a serial manner. In present study (Table 1b) on admission mean serum albumin levels in patients of head injury were $3.760 \pm 0.339 \mathrm{~g} / \mathrm{dl}$ as compared to control $4.214 \pm 0.186 \mathrm{~g} / \mathrm{dl}$ and statistically significant difference was found $(p<0.001)$. This finding is comparable with study of Dhandapani SS et $\mathrm{al}^{11}$ where the admission mean serum albumin levels in patients of head injury were $(3.24, \mathrm{SD} \pm 0.52 \mathrm{~g} / \mathrm{dl})$ as compared with the control $(4.15, \mathrm{SD} \pm 0.48 \mathrm{~g} / \mathrm{dl})$.

The mean serum total protein levels was showed insignificant increase in the first week as in the study of Dhandapani SS et $\mathrm{al}^{9}$ which is comparable with our present study as on day 1 the mean serum total protein was 6.15 $(\mathrm{SD} \pm 0.94) \mathrm{g} / \mathrm{dl}$ and on $10^{\text {th }}$ day $6.18(\mathrm{SD} \pm 0.92) \mathrm{g} / \mathrm{dl}$, levels showed insignificant $(\mathrm{p}=0.548)$ increase(Figure $1 \mathrm{a})$. This finding is explained by Veldee MS et $\mathrm{al}^{3}$ as serum total protein levels did not show significant difference, possibly due to conflicting effect of increased positive acute phase reactants such as $C$ reactive protein (CRP), á-1 acid glycoprotein \& á-1 antitrypsin and decreased serum albumin levels.

Dhandapani SS et $\mathrm{al}^{11}$ in his study was defined the hypoalbuminemia at admission when serum albumin $\leq 3.5 \mathrm{~g} / \mathrm{dl}$ and there was a significant falling trend in admission serum albumin levels with decrement in GCS as hypoalbuminemia which is similar to our study findings.

In this study (Table 1c) it was also noted that $77.7 \%$, $45.4 \%, 31.4 \%$ male and $42.8 \%, 28.5 \%, 27.2 \%$ female having hypoalbuminemia $(<3.5 \mathrm{gm} / \mathrm{dl})$ in severe, moderate and mild head injury respectively and the difference was statistically significant for severe and moderate head injury but insignificant in mild head injury group. The less hypoalbuminemia in our present study population in all GCS category when comparing to others studies is due to female patient having less frequent fall in albumin when comparing with others studies. Bernard F, et $\mathrm{al}^{6}$ cohort had a outcome $70 \%$ favorable and 30\% unfavorable at 6 months with $22(16 \%)$ of them died. Like that in present study cohort $76.5 \%$ favorable outcome and $23.5 \%$ unfavorable outcome at 6 months with $23(11.5 \%)$ of them died (Table $1 \mathrm{~d})$.
Dhandapani SS et $\mathrm{al}^{11}$ was noted unfavorable outcome at 3 months in $62 \%$ of patients having admission hypoalbuminemia, as compared to $18 \%$ of those having normal levels $(p<0.001)$. The association of admission hypoalbuminemia with unfavorable outcome was uniform throughout all grades of head injury and the association was significantly stronger in non-surgical patients. In present study unfavorable outcome at 6 months was noted in $76.6 \%$ of patients having admission hypoalbuminemia $(<3.5 \mathrm{gm} / \mathrm{dl})$, as compared to $23.4 \%$ of those having normal levels and the difference was statistically highly significant $(p<0.001) .26$ patients were managed surgically in which $22(14.4 \%)$ patient in favorable group and 4 patients in unfavorable group (Figure 1c) with statistically insignificant differences $(\mathrm{p}=0.295)$. So it is less likely that surgical patients affect results here.

In study of Dhandapani SS et $\mathrm{al}^{9}$ the Glasgow outcome score at 6 months was available for 40 patients of GCS (4-8). The unfavorable outcome was noted in 12 out of 15 patients with at least $15 \%$ fall in serum albumin levels at 3 weeks, as compared to 11 out of 25 patients with less than $15 \%$ fall in serum albumin and the difference was statistically significant. In our study (Table 2a) the unfavorable outcome was noted in 28 out of 50 patients of GCS (4-8) the fall in serum albumin from day 1 of admission to $10^{\text {th }}$ day was $17.87 \%$.

In this study (Table 2b) fall in serum albumin was 18.65\% from day1 to day10 in unfavorable group comparing to $8.63 \%$ in favorable group. These our above mentioned findings were correlated with literatures as mentioned by Bernard $\mathrm{F}$, et $\mathrm{al}^{6}$ albumin levels were higher in the first few days after injury in patients with a good outcome. The albumin levels decreased appreciably compared with normal values in both favorable and unfavorable groups. However, the albumin levels remained below $2.5 \mathrm{gm} / \mathrm{dl}$ for a longer period of time in the group with a bad outcome ( 3 days vs. 6 days; $\mathrm{p}<0.012$ ). Recently, Yang TJ et $\mathrm{al}^{12}$ and colleagues performed a retrospective cohort study, and concluded that the most favorable level of albumin for uncomplicated severe TBI is 2.9-3.1 gm/dl. Taking consideration of above literatures and our study results showed that there is a steady fall in serum albumin in both groups. However the fall in unfavorable group is more steep than favorable. It suggests that the rapidity with which serum albumin level falls has an effect on the outcome and prognosis of the patient this is similar to McCluskey A et $\mathrm{al}^{13}$ study which reports that serum albumin levels decreased more steeply in non survivors. A steep decline in serum albumin indicates a poor prognosis. Du Chen et $\mathrm{al}^{8}$ results demonstrated, in patients of TBI with serum albumin $\geq 3.5 \mathrm{gm} / \mathrm{dl}$, the proportion of unfavorable outcome was reduced significantly. In our present study the 
proportion of unfavorable outcome was reduced highly significantly $(\mathrm{p}<0.001)$ where serum albumin $\geq 3.5 \mathrm{gm} / \mathrm{dl}$.

Serum albumin levels in patients of head injury did not show significant gender difference (Mean values 3.3 vs. $3 \mathrm{~g} / \mathrm{dl}) .{ }^{7}$ But in present study the female patients having higher mean serum albumin compare to male on all days $(1,3,5,10)$ and statistically significant differences was observed on $10^{\text {th }}$ day $(\mathrm{p}=0.045)$ (Table $2 \mathrm{c}$ ).

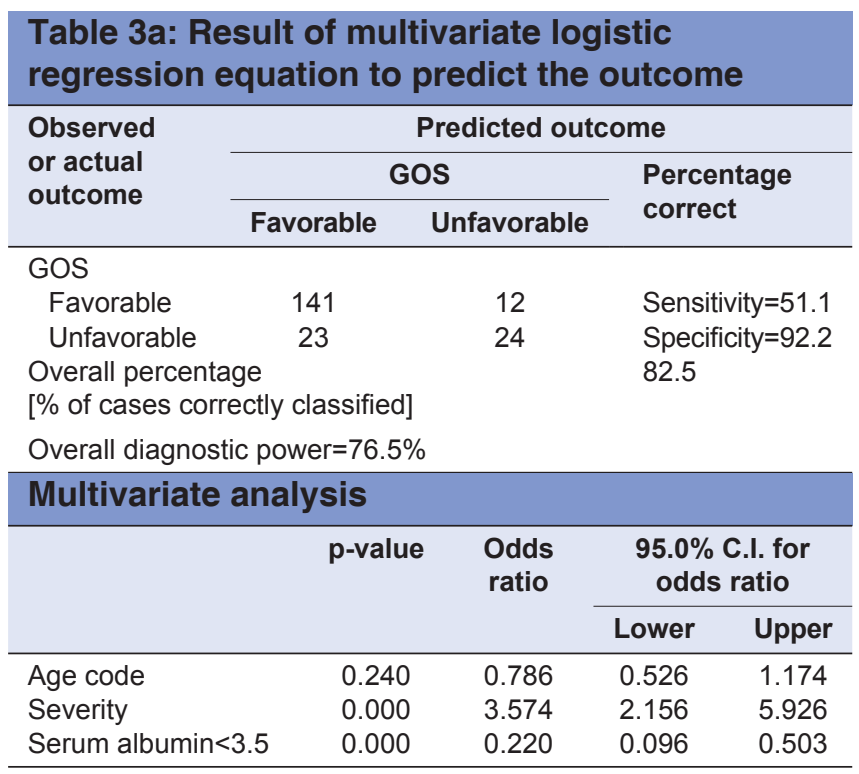

Table 3b: Result of multivariate logistic
regression equation to predict the outcome and
mortality.

\begin{tabular}{|c|c|c|c|c|c|}
\hline & Sensitivity & Specificity & Accuracy & NPV & PPV \\
\hline $\begin{array}{l}\text { Serum albumin } \\
\text { levels on day } \\
1,3,5 \text { and day } \\
10(\%)\end{array}$ & 95.65 & 85.88 & 87 & 99.35 & 46.81 \\
\hline
\end{tabular}

Males are more likely to suffer from a critical illness than females Blunt $\mathrm{MC}$ et $\mathrm{al}^{14}$ keeping in view the literatures facts our study results also shows that in severe head injury group means critically ill where the serum albumin $<3.5 \mathrm{gm} / \mathrm{dl}$ the mortality is more for male patients compare to female. Female patients having less hypoalbuminemia in both favorable and unfavorable group of TBI with less steeper fall in serum albumin from day1 to day 10. This is the possible explanation of better outcome here for females suffering from TBI.

In our study(Figure 1b) of 200 TBI patients 177 patients $(88.5 \%)$ were discharged (survivors) from the hospital and 23 patients $(11.5 \%$ ) expired (non survivors) in the hospital similarly McCluskey A et $\mathrm{l}^{13}$ study has reported $70 \%$ survivors and 30\% non-survivors. Another study of Blunt MC et al ${ }^{14}$ was reported $54 \%$ survivors and $46 \%$ non survivors.

In our study, (Table 2d) mean serum albumin level on day of admission (Day 1) for the study group was $3.76 \mathrm{~g} / \mathrm{dl}( \pm 0.4 \mathrm{gm} / \mathrm{dl})$ and in survivors, it was $3.81 \mathrm{gm} / \mathrm{dl}$ $( \pm 0.3 \mathrm{gm} / \mathrm{dl})$ and highly significantly lower $(\mathrm{p}<0.001)$ in non survivors $3.35 \mathrm{gm} / \mathrm{dl}( \pm 0.6 \mathrm{~g} / \mathrm{dl})$. In the survivor group, $62.71 \%$ patients have normal serum albumin levels on admission as compared to just $8.75 \%$ in the non survivor group, suggesting hypoalbuminemia at admission indicates a poorer prognosis in terms of increased mortality. In Yap FM, et $\mathrm{al}^{15}$ study survivors had higher admission albumin $(2.57 \mathrm{~g} / \mathrm{dl}$ vs $2.10 \mathrm{~g} / \mathrm{dl}, \mathrm{p}<0.005)$ than non survivors. In Banga $\mathrm{A}$, et $\mathrm{al}^{16}$ study, the mean serum albumin levels on day one were reported to be $3.2 \mathrm{~g} / \mathrm{dl}$ $( \pm 0.7 \mathrm{~g} / \mathrm{dl})$ which is comparable to our study as in present study, the mean level of serum albumin on day three in study group was $3.51 \mathrm{~g} / \mathrm{dl}( \pm 0.4 \mathrm{gm} / \mathrm{dl})$. In survivors it was $3.58 \mathrm{gm} / \mathrm{dl}( \pm 0.51 \mathrm{~g} / \mathrm{dl})$ and in non survivors it was $3.01 \mathrm{gm} / \mathrm{dl}( \pm 0.22 \mathrm{~g} / \mathrm{dl})$. It was significantly lower $(\mathrm{p}<0.001)$ in non survivors. Banga $\mathrm{A}$, et $\mathrm{al}^{16}$ study the day three levels of serum albumin in non survivors was $2.9 \mathrm{~g} / \mathrm{dl}( \pm 0.6 \mathrm{~g} / \mathrm{dl})$ which is similar to our study.

The study shows here the mean duration of Neuro ICU stay and mechanical ventilation was significantly higher in hypoalbuminemia group (Figure 1d).

McCluskey A et al, ${ }^{13}$ Blunt MC et $\mathrm{al}^{14}$ and Nicholson JP et $\mathrm{al}^{17}$ studies, reported that nonsurvivors had lower serum albumin concentrations on admission to the ICU, and their albumin concentrations decreased more rapidly in the first 24 to $48 \mathrm{~h}$. This explains the longer ICU stay of unfavorable group in our study.

Sapijaszko MJA, et $\mathrm{al}^{18}$ studies reports that albumin concentration on ICU admission was not a predictor of 
the length of time spent receiving mechanical ventilation. However, the profiles of changes in serum albumin concentration have a predictive value. Present study was also noted a continuous decrease in serum albumin levels in unfavorable group.

Nelson DW, et a ${ }^{19}$ and various other studies reported that low level of serum albumin seems to be an independent predictor for poor outcome of TBI. Lower level of albumin is bound to weaken the patient's resistance, resulting in slow wound healing and fragile resistance to secondary infection. Eventually, the risk of poor prognosis is significantly increasing., ${ }^{6,8}$ Results of our study give this a further confirmation as in our study (Figure 1e) the complications like infection, delayed wound healing was higher for unfavorable group $(14.9 \%)$ than in favorable group (8.5\%).

In our study (Table 3b \& c) the logistic regression equation is correctly predict the outcome of nonsurvivors is $85.88 \%$. These our study findings are comparable with study of Mc Cluskey A. et $\mathrm{al}^{13}$ where he was compared the outcome of the patients based on serum albumin measurements at admission, at 12-24 hours, at 24-48 hours and at 48-72 hours, reported 48-72 hours serum albumin to be $53.7 \%$ sensitive and $84.8 \%$ specific with accuracy of $74.2 \%$. This difference between our study and Mc Cluskey A. et a $1^{13}$ study was observed because of the difference in sample size of patients, different timing of serial measurement of serum albumin from the time of admission and etiology of tissue damage.

In the analysis of all patients, in our study (Table $3 \mathrm{a} \& \mathrm{~b}$ ) after adjustment for the effects of age, GCS both univariate and multivariate logistic regressions model determined serum albumin less than $3.5 \mathrm{~g} / \mathrm{dl}$ and severity of GCS was found to be highly significantly, associated with unfavorable outcome. Both factors were emerging as independent predictors for of TBI at 6 months. The our findings are comparable with Dhandapani SS et al ${ }^{11}$ Bernard F, et al ${ }^{6}$ and Du Chen, et al. ${ }^{8}$

Yurchenco PD et al $^{20}$ studies was explaining different mechanisms for the decline of serum albumin in patients with TBI. Firstly, albumin consumption is increased under stress state. Secondly, hemorrhage caused albumin lost. Thirdly, inadequate intake and the suppressed liver function would reduce albumin synthesis. In addition, albumin extravasation due to increased vascular permeability and blood brain barrier dysfunction. Rossi JL et $\mathrm{al}^{21}$ and colleagues performed an experiment which explains the mechanism of reduced albumin which leads to the poor prognosis of TBI from the aspect of the blood-brain barrier integrity.
Rodling WM et $\mathrm{al}^{22}$ and colleagues reported that a protocol including albumin administration in combination with a neutral to a slightly negative fluid balance was associated with low mortality in patients with severe TBI. Findings from animal experiment may explain the mechanism partly. Belayev L et $\mathrm{al}^{23}$ was observed in his experimental study, that high-concentration albumin therapy instituted $15 \mathrm{~min}$ after trauma significantly improves the neurological score and reduces histological damage. Du Chen et $\mathrm{al}^{8}$ recently in 2014 recommend that it would be better to maintain a moderately high level of serum albumin for patients of TBI based on his results and related studies.

Our studies results showed that there is a broad therapeutic window as the decline of serum albumin is showed from day 1 to day 10. These findings were further confirmed with the study of Dhandapani SS et $\mathrm{al}^{9}$ in this study the nadir of serum albumin levels was noted at second week followed by partial but significant restitution similar to the findings of Young et $\mathrm{al}^{10}$ and this may suggest a possible window period. Further confirmed by Belayev L et al ${ }^{24}$ in his study reported that albumin also has a favorable therapeutic time window allowing administration within a clinically feasible delay.

\section{CONCLUSION}

Based on our results low level of serum albumin is a risk factor for TBI, and the percentage of favorable outcome decreases with hypoalbuminemia. It would be better to maintain the level of serum albumin more than $3.5 \mathrm{gm} / \mathrm{dl}$ in traumatic brain injury patients specifically in severe head injury. The female patients performed better in all subgroups due to less steep fall in serum albumin. There may be a therapeutic window from day 1 to day 10 .

\section{ACKNOWLEDGEMENT}

Very much thanks to Dr. Tapas K Sirkar for his valuable suggestions in making this manuscript.

\section{REFERENCES}

1. Reilly PL. Brain injury: the pathophysiology of the first hours. 'Talk and Die revisited'. J Clin Neurosci 2001; 8: 398-403.

2. McClain CJ, Hennig B, Ott LG, Goldblum $S$ and Young AB. Mechanisms and implications of hypoalbuminemia in head injured patients. J Neurosurg 1988; 69(3): 386-392.

3. Veldee MS: Nutritional assessment, therapy and monitoring. In: Burtis CA, Ashwood ER (eds), Tietz Textbook of Clinical Chemistry, $3^{\text {rd }}$ Ed. Philadelphia, WB Saunders, 1999; pp13591394.

4. Berger RP. The use of serum biomarkers to predict outcome after traumatic brain injury in adults and children. J Head Trauma Rehabil 2006; 21(4); 315-333. 
5. Albumin for Intracerebral Hemorrhage Intervention (ACHIEVE). http://clinicaltrials.gov/ct2/show/NCT00990509. Accessed 16 Mar 2010.

6. Bernard F, Al-Tamimi YZ, Chatfield D, Lynch AG, Matta BF and Menon DK. Serum albumin level as a predictor of outcome in traumatic brain injury: Potential for treatment. J Trauma 2008; 64(4): 872-875.

7. Gosling P. Albumin and the critically ill. Care Crit III 1995; 11: $57-61$.

8. Du Chen, Long Bao, Shi-qi Lu and Feng Xu. Serum Albumin and Prealbumin Predict the Poor Outcome of Traumatic Brain Injury. PLOS ONE 2014; 9 (3): 1-7.

9. Dhandapani SS, Manju D, Vivekanandhan S, Agarwal M and Mahapatra AK. Prospective longitudinal study of biochemical changes in critically ill patients with severe traumatic brain injury: Factors associated and outcome at 6 months. Indian Journal of Neurotrauma 2010; 7(1): 23-28.

10. Young B, Ott L, Beard D, et al. The acute phase response of brain injured patients. J Neurosurg. 1988; 69: 375-80.

11. Dhandapani SS, Manju D, Vivekanandhan S, Sharma BS and Mahapatra AK. Prognostic value of admission serum albumin levels in patients with head injury. Pan arab journal of neurosurgery 2009; 13: 60-65.

12. Yang TJ, Fei MM, Ye W, Pan AJ and Liu B. Effect of albumin and hemoglobin level on prognosis of patients with uncomplicated severe traumatic brain injury: a retrospective cohort study. Zhonghua Wei Zhong Bing Ji Jiu Yi Xue 2013; 25: 301-305.

13. McCluskey A, Thomas AN, Bowles BJM and Kishen R. The prognostic value of serial measurements of serum albumin in patients admitted to an intensive care unit. Anaesthesia 1996; 51: 724-727.

14. Blunt MC, Nicholson JP and Park GR. Serum albumin and colloid osmotic pressure in survivors and non-survivors of prolonged critical illness. Anaesthesia 1998; 53: 755-761.
15. Yap FM, Joynt GM, Buckley TA and Wong ELY. Association of serum albumin concentration and mortality Risk in Critically ill patients. Anaesth Intensive Care 2002;30(2):202-207.

16. Banga A, Guleria R, Khilnani GC and Khanna S. Serum albumin as A Prognostic Marker in Critically ill patients. JAPI 2003; 51:1223-1224.

17. Nicholson JP, Wolmarans MR and Park GR. The role of albumin in critical illness. Br J Anaesth 2000; 85: 599-610.

18. Sapijaszko MJA, Brant R, Sandham D and Berthiaume Y. Nonrespiratory predictor of mechanical ventilation dependency in intensive care unit patients. Crit Care Med 1996; 24: 601-607.

19. Nelson DW, Rudehill A, MacCallum RM, Holst A, Wanecek M, Weitzberg E, et al. Multivariate outcome prediction in traumatic brain injury with focus on laboratory values. J Neurotrauma 2012; 29: 2613-2624.

20. Yurchenco PD and Schittny JC. Molecular architecture of basement membranes. FASEB J.1990; 4: 1577-1590.

21. Rossi JL, Ralay Ranaivo H, Patel F, Chrzaszcz M, Venkatesan C and Wainwright MS. Albumin causes increased myosin light chain kinase expression in astrocytes via p38 mitogen-activated protein kinase. J Neurosci Res 2011; 89:852-861.

22. Rodling WM, Olivecrona M, Nystrom F, Koskinen LO and Naredi S. Fluid therapy and the use of albumin in the treatment of severe traumatic brain injury. Acta Anaesthesiol Scand 2009; 53: 18-25.

23. Belayev L, Alonso OF, Huh PW, Zhao W, Busto $R$ and Ginsberg MD. Post treatment with high-dose albumin reduces histopathological damage and improves neurological deficit following fluid percussion brain injury in rats. J Neurotrauma 1999; 16:445-453.

24. Belayev L, Liu Y, Zhao W, Busto R and Ginsberg MD. Human albumin therapy of acute ischemic stroke: marked neuroprotective efficacy at moderate doses and with a broad therapeutic window. Stroke 2001; 32:553-560. 